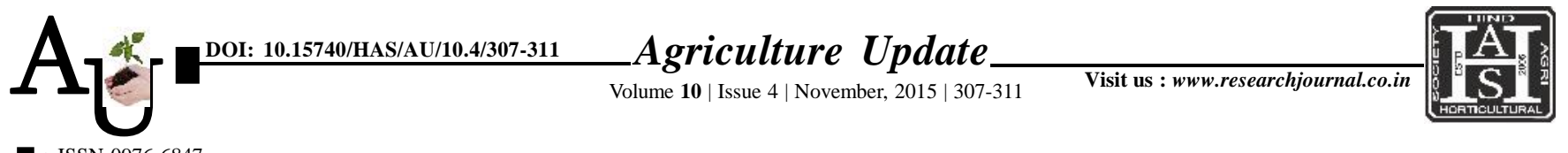

\title{
Research Article: Constraints faced by the respondents in adoption of sugarcane production technologies
}

\section{A.V. KHANDRE, J.V. EKALE AND R.D. AHIRE}

Article Chronicle: Received : 20.10.2015;

Revised :

25.09.2015;

Accepted :

11.10.2015

\section{KEY WoRds:}

Constraints,

Suggetions,

Sugarcane crop,

Sugarcane production technology,

Sugarcane growers

Author for correspondence :

\section{A.V. KHANDRE}

Department of

Extension Education,

Vasantrao Naik

Marathwada Krishi

Vidyapeeth, PARBHANI

(M.S.) INDIA

Email:khandreav@

gmail.com

See end of the article for authors' affiliations
SUMMARY : The present study was conducted with specific objectives to study knowledge and adoption of sugarcane production technology. For this study Latur district was selected and from Latur district two talukas viz., Chakur and Udgir were selected. From these two talukas twelve villages were selected randomly and ten respondents from each village were selected, i.e. 120 respondents from 12 villages constituted the sample for the study. Ex-Post Facto research design was used for the research study. The major constraints faced by respondents in adoption of sugarcane production technologies were lack of knowledge about the identification of insect and pest, lack of availability water and lack of knowledge about scientific plant protection measures. The majority of the respondents suggested that information should be provided about identification of insect and pests of sugarcane crop and their proper control measures, permanent water resources should be available i.e. farm pond and to provide the information about sett treatment.

How to cite this article: Khandre, A.V., Ekale, J.V. and Ahire, R.D. (2015). Constraints faced by the respondents in adoption of sugarcane production technologies. Agric. Update, 10(4): 307-311. 